\title{
THE EFFECT OF CORTICOTROPIN (ACTH) ON GLOMERULAR PERMEABILITY TO ALBUMIN IN CHILDREN WITH THE NEPHROTIC SYNDROME 1,2
}

\author{
By HENRY D. LAUSON, CAROLYN W. FORMAN, 3 HELEN MCNAMARA, \\ GUILHERME MATTAR 4 AND HENRY L. BARNETT
}

\author{
(From the Departments of Pediatrics and Physiology, The New York Hospital-Cornell Medical \\ Center, New York, N. Y.)
}

(Submitted for publication February 9, 1953; accepted June 24, 1953)

Present evidence indicates that proteinuria in patients with the nephrotic syndrome is the result of increased permeability of the glomerular capillary walls to proteins, particularly to albumin (1, 2 ). A rough indication of the permeability to albumin, relative to permeability to water, is provided by the ratio of the concentration of albumin in glomerular fluid to that in plasma. Assuming that no albumin is excreted by the tubules, the rate of albumin excretion (in mg. per min.) divided by the rate of glomerular filtration of water (GFR, in $\mathrm{ml}$. per min.) represents the lowest possible concentration of albumin in glomerular fluid (in $\mathrm{mg}$. per $\mathrm{ml}$.) ; if some albumin is reabsorbed by the tubules, as seems likely, the actual concentration of albumin in glomerular fluid would be greater than this calculated value. If it is accepted that the clearance of inulin $\left(\mathrm{C}_{\mathrm{IN}}\right)$ is equivalent to GFR in children with the nephrotic syndrome ( 3 ), it follows that the renal clearance of albumin $\left(\mathrm{C}_{\triangle \mathrm{LB}}\right)$ divided by $\mathrm{C}_{\mathrm{IN}}$, i.e., $\mathrm{C}_{\mathrm{ALB}} / \mathrm{C}_{\mathrm{IN}}$, represents the minimum ratio of the albumin concentration in glomerular fluid to that in plasma.

Chinard, Lauson, and Eder (4) showed that in patients with the nephrotic syndrome the renal clearance of the blue dye, T-1824 $\left(\mathrm{C}_{\mathrm{T}-1824}\right)$, was somewhat less than but approximately proportional to $\mathrm{C}_{\mathrm{ALB}}$. It would appear, therefore, that where large changes in permeability are expected $\mathrm{C}_{\mathrm{T}-1824}$ should be a satisfactory substitute for $C_{A L B}$. The

\footnotetext{
1 Presented in part before the Society for Pediatric Research, Atlantic City, May, 1951.

2 Supported in part by a grant from the National Institutes of Health, Public Health Service.

3 Public Health Service Post-Doctorate Research Fellow, 1949-1951. Present address: Dept. of Pediatrics, Stanford University School of Medicine, San Francisco, Calif.

4 Mead Johnson-Society for Pediatric Research Fellow in Pediatrics, 1950-1951. Present address: University Hospital, São Paulo, Brazil.
}

methods for determining concentrations of the dye in serum and urine (4) are much easier than the immunochemical method for albumin $(1,5)$.

In many patients with the nephrotic syndrome, proteinuria diminished during or after treatment with corticotropin (ACTH) or Cortisone (6-17). Further, in most patients so treated GFR increased $(6-8,12)$. These observations suggested that glomerular permeability to albumin decreased under the influence of treatment. The present study was undertaken to estimate the order of magnitude of this change in permeability. A preliminary report of this work has been previously published (18).

\section{METHODS}

A. Patients. Clinical data are summarized in Table I. All patients received ACTH intramuscularly every six hours in the dosage indicated. One child, F. deK., had had no edema for several years; as measured by the urea clearance, renal function had remained about 40 per cent of normal during those years. Proteinuria varied between 1 and $2 \mathrm{Gm}$. per 24 hours in this patient prior to treatment with ACTH.

B. Procedures. Clearances of T-1824 ( $\left.\mathrm{C}_{\mathrm{T}-1824}\right)$, specific endogenous creatinine $\left(C_{C_{R}}\right)$, inulin $\left(C_{I N}\right)$ and p-aminohippurate $\left(\mathrm{C}_{\mathrm{PAB}}\right)$ and the plasma volume were estimated before, during, and after courses of ACTH. Food and fluids were withheld for at least 12 hours before each test. The procedure followed in most observations was as follows : Beginning about 8 a.m., a control urine specimen ( $\left.U_{0}\right)$ was obtained through an indwelling catheter. The bladder was washed out only with air. A control blood specimen was taken $\left(B_{0}\right)$. Pipetted 2 or $3 \mathrm{ml}$. aliquots of 0.5 per cent $\mathrm{T}-1824$ were then injected intravenously by the method of Barnett and Fellers (19). After 10 minutes a venous blood sample was withdrawn $\left(B_{1}\right)$. Another aliquot of dye was delivered by the same pipette into a volumetric flask, the volume of which was roughly one-fifth of the expected plasma volume. This, filled to the mark with physiologic saline, was the "reference solution" (20). Several minutes later the bladder was washed out with air and the urine saved for total protein determination in most observations. The urine 
for estimation of $C_{T-1 m}\left(U_{1}\right)$ was collected 10 to $31 \mathrm{~min}$ utes later; another blood sample $\left(B_{2}\right)$ was taken soon thereafter. Priming doses of inulin and PAH were next injected intravenously, and a sustaining infusion of these substances in physiologic saline was administered at a rate of $0.5 \mathrm{ml}$. per min. by means of a Bowman constant infusion pump. After an equilibration period of about one hour, three urine collections were made, each of 10 to 20 minutes duration $\left(U_{2-4}\right)$; blood was withdrawn before $\mathrm{U}_{2}$ and after $\mathrm{U}_{4}$. Concentrations of inulin and of $\mathrm{PAH}$ in plasma in the several patients ranged between 27 and 109 and between 0.5 and $3.3 \mathrm{mg}$. per $100 \mathrm{ml}$, respectively. $C_{C R}$ was calculated for all periods, $C_{T-1824}$ for $U_{1}$, and $C_{I N}$ and $C_{P A B}$ for $U_{2-4}$. The presence of inulin in high concentration made it impossible to clarify most of the urines by centrifugation and therefore interfered with the determination of dye concentration. It was for this reason that $\mathrm{C}_{\mathrm{T}-18 \mathrm{a}}$ was measured prior to administration of inulin. To estimate $C_{T-18 e t} / C_{I N}$, the ratio $C_{T-184} / C_{C R}$ for period $\mathrm{U}_{1}$ was multiplied by the average $\mathrm{C}_{\mathrm{CR}} / \mathrm{C}_{\mathrm{IN}}$ ratio obtained during the subsequent periods $U_{2-4}$. Similarly, to estimate total protein excretion/ $\mathrm{C}_{\mathrm{IN}}$, the ratio of total protein excretion/Cor for the period preceding $U_{1}$ was multiplied by the average $\mathrm{C}_{\mathrm{CR}} / \mathrm{C}_{\mathrm{IN}}$ ratio.

C. Analytical methods. Inulin concentration in cadmium filtrates (21) of serum and in suitably diluted urine was determined by the method of Schreiner (22). Omitting precipitation of protein in these urines introduced no error in the inulin determination of more than 2 per cent. The concentration of $P A H$, also in cadmium filtrates of serum and diluted, unprecipitated urine, was determined by a modification of the method of Bratton and Marshall (21).

Specific endogenous creatinine was determined by a modification of the method of Hare (23). In the earlier cases, serum protein was precipitated $(1: 5)$ by the tungstic acid method of Wu (24), and the urine protein was not precipitated. Later, the proteins of both serum and urine were precipitated $(1: 5)$ by trichloroacetic acid. Ten $\mathrm{ml}$. aliquots of serum filtrates and of diluted urine, as well as the standard solutions of creatinine zinc chloride, were all made up to contain 5 per cent trichloroacetic acid. One ml. of saturated oxalic acid and approximately $40 \mathrm{mg}$. of Lloyd's reagent were added. After frequent shaking during a 10-minute period the solution was centrifuged and the supernate carefully aspirated. The creatinine adsorbed to Lloyd's reagent was eluted by adding 5 $\mathrm{ml}$. of alkaline picrate (Hare's formula [23]) and shaking frequently during a 10-minute period. After centrifugation the clear supernate was transferred with a Wintrobe pipette to an $18 \times 150 \mathrm{~mm}$. cuvette; the optical density was read in a Coleman Model 6A clinical spectrophotometer at a wave length setting of $500 \mathrm{~m} \mu$. A portion of the light aperture of the cuvette holder was blocked off by black cellophane tape. By eluting the creatinine from $10 \mathrm{ml}$. of serum filtrate into $5 \mathrm{ml}$. of alkaline picrate an additional two-fold concentration was achieved (in effect, the serum creatinine was diluted only $1: 2.5$ ). Thus the very low concentrations frequently encountered in small children (i.e., as little as 0.15 to $0.20 \mathrm{mg}$. per $100 \mathrm{ml}$. of serum) could be estimated with satisfactory accuracy. The concentrations in two or three successive serum samples were averaged and this average value was used in calculating $\mathrm{C}_{\mathrm{CR}}$ for all periods.

$T-1824$ in the serum was estimated by the acetone extraction procedure of Chinard and Eder (20). The concentration of dye in urine clarified by centrifugation was determined by a modification of the method of Chinard, Lauson, and Eder (4). All urines were buffered

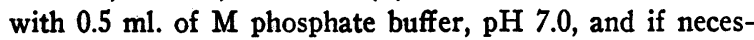
sary diluted with physiologic saline. Final volumes varied from 2 to $5 \mathrm{ml}$. Because the urinary blank was often relatively large, and because the dye excretion was usually quite low after ACTH, several "corrections" were made to secure maximum accuracy in calculating $C_{T-1824}$. Optical density was read both at $620 \mathrm{~m} \mu$ and $450 \mathrm{~m} \mu$, the instrument being set to zero optical density with a control solution of saline and buffer.5 The "corrected" optical density at $620 \mathrm{~m} \mu$ of $\mathrm{U}_{1}$ in the pre-ACTH study was calculated by the equation:

$$
\text { "corrected" } D_{620}=\frac{\text { observed } D_{620}-K_{1} \times \text { observed } D_{450}}{1-K_{1} / K_{2}},
$$

where $D_{000}$ and $D_{450}$ are the optical density of $U_{1}$ at 620 $\mathrm{m} \mu$ and $450 \mathrm{~m} \mu$, respectively; $\mathrm{K}_{1}$ is the optical density at $\lambda=620 \mathrm{~m} \mu$ of the control urine $\left(U_{0}\right)$ of the pre-ACTH study divided by its optical density at $\lambda=450 \mathrm{~m} \mu ; \mathrm{K}_{2}$ is the increment in optical density at $\lambda=620 \mathrm{~m} \mu$ divided by that at $\lambda=450 \mathrm{~m} \mu$ due to addition of a known amount of dye to $U_{0}$ (i.e., the optical density of $U_{0}$ at each wavelength was subtracted from that of $\left.\left[U_{0}+d y e\right]\right)$. "Corrected" concentration in $U_{1}$ was calculated as:

"Corrected" concentration

$$
\begin{gathered}
=\frac{\text { "corrected" } \mathrm{D}_{620}\left(\text { of } \mathrm{U}_{1}\right)}{\mathrm{D}_{620} \text { (of } \mathrm{U}_{0}+\text { dye) }-\mathrm{D}_{620}\left(\text { of } \mathrm{U}_{0}\right)} \\
\times \text { concentration of dye in }\left(\mathrm{U}_{0}+\text { dye }\right) \\
\times \text { dilution factor of } \mathrm{U}_{1} .
\end{gathered}
$$

"Corrected" dye excretion is the product of the concentration and urine flow. ${ }^{6}$

5 Under the conditions of the studies reported here the molar concentration ratios of albumin to dye in the plasma, and therefore also in the glomerular filtrate, were well within the range of $1: 1$ to $1: 100$. Therefore, it may reasonably be assumed that variations in the absorption coefficient of the dye in the urines were relatively unimportant (4).

- An example will make clear how these corrections were applied. In patient W. H. (2-7-51), the optical densities of $U_{0}$ and $U_{1}$ at $\lambda=620 \mathrm{~m} \mu$ were 0.013 and 0.270 , respectively; at $\lambda=450 \mathrm{~m} \mu$, optical densities of $U_{0}$ and $U_{1}$ were 0.071 and 0.099 , respectively. The optical density of $\left(\mathrm{U}_{0}+\right.$ dye $)$ at $\lambda=620 \mathrm{~m} \mu$ was 0.449 and at $\lambda=450 \mathrm{~m} \mu$ was 0.125 . Therefore, $K_{1}=\frac{0.013}{0.071}=0.183$; $\mathrm{K}_{2}=\frac{0.449-0.013}{0.125-0.071}=8.02 ; \mathrm{K}_{1} / \mathrm{K}_{2}=\frac{0.183}{8.02}=0.023$. The concentration of dye in $\left(U_{0}+\right.$ dye) was $10.0 \mu \mathrm{g}$. per 
In the subsequent studies on each patient, there was often a small residual excretion of $\mathrm{T}-1824$, due to dye administered during the preceding study.7 For this reason, additional calculations were necessary. $\mathrm{K}_{1}$ of the first study was inserted in the equation and the "corrected" $D_{020}$ and concentration were calculated for $U_{0}$ as well as $U_{1}$. Multiplying the concentrations (in $\mu \mathrm{g}$. per $\mathrm{ml}$.) by the respective urine flow rates, $\mathrm{V}$ (in $\mathrm{ml}$. per $\mathrm{min}$.), the corrected excretion rates, $\mathrm{UV}$, for $\mathrm{T}-1824$ were obtained (in $\mu \mathrm{g}$. per min.). To reduce errors which might have arisen from improper bladder emptying or change in GFR, the following calculation was made:

"Corrected" $\left(\mathrm{U}_{\mathrm{T}-1824} \mathrm{~V}\right)_{\mathrm{U}_{1}}$

$$
=\left[\left(\frac{\mathrm{U}_{\mathrm{T}-1824} \mathrm{~V}}{\mathrm{C}_{\mathrm{CR}}}\right)_{\mathrm{U}_{1}}-\left(\frac{\mathrm{U}_{\mathrm{T}-1824} \mathrm{~V}}{\mathrm{C}_{\mathrm{CR}}}\right)_{\mathrm{U}_{0}}\right]\left(\mathrm{C}_{\mathrm{CR}}\right)_{\mathrm{U}_{1}} \text {. }
$$

To calculate $C_{T-1824}$, the "corrected" excretion rate was divided by the concentration in serum interpolated at the midpoint of $U_{1}$ from a semi-logarithmic plot of the concentrations in the serum of $B_{1}$ and $B_{2}$. The optical density of the control serum $\left(B_{0}\right)$ of the same day was subtracted from that of the two dye-stained sera. Usually this correction was negligible (less than 0.003 optical density units).

Plasma and whole blood volumes were calculated in the manner described by Chinard and Eder (20).

Total protein concentration in the urine of the control period immediately preceding $U_{1}$ was determined by the biuret method of Hiller, Greif, and Beckman (25). In a few cases, the clearance of albumin and $C_{T-182}$ were

ml.; $U_{1}$ had been diluted 1:4. Urine flow during $U_{1}$ was $0.136 \mathrm{ml}$. per min. The "corrected" optical density of $U_{1}$ at $\lambda=620 \mathrm{~m} \mu$ therefore was: $D_{620}=\frac{0.270-0.183 \times 0.099}{1-0.023}$ $=0.258$. The "corrected" concentration of dye in $U_{1}$ was: "corrected" concentration $=\frac{0.258}{0.449-0.013} \times 10.0$ $\mu \mathrm{g} . / \mathrm{ml} . \times \frac{4}{1}=23.0 \mu \mathrm{g} . / \mathrm{ml}$. "Corrected" $U_{1} V_{1}=23.0$ $\times 0.136=3.13 \mu \mathrm{g} . / \mathrm{min}$. The interpolated midpoint concentration in serum was $17.1 \mu \mathrm{g} . / \mathrm{ml}$. Hence $C_{T-1824}$ $=0.183 \mathrm{ml}$. per $\mathrm{min}$.

7 In one of the subsequent studies, the control urine had a distinctly blue color. After centrifugation, most of the color was found concentrated in the sediment; microscopically, most of the dye could be seen in urinary tract epithelial cells, presumably in desquamated renal tubule epithelium. The dye slowly diffused from the cells on repeated extraction with physiological saline. Routinely, all urine specimens were centrifuged about one hour after the last clearance period preparatory to determining the dye concentration. It is assumed that the amount of dye diffusing from the cells of the sediment during the interval before centrifugation contributed about the same amount of dye (expressed as $\mu \mathrm{g}$. per minute) to the control urine $\left(U_{0}\right)$ as to subsequent urines; the resulting errors would, therefore, approximately cancel. In several other observations, the amount of dye concentrated in the sediment was much less than in the one described. estimated concurrently to learn if the proportionality observed by Chinard, Lauson, and Eder (4) obtained under the conditions of the present studies, i.e., during or after ACTH therapy. The immunochemical method used to estimate albumin concentration in urine and plasma was essentially that described by Kunkel and Ward (5). In the present investigation, however, twice-crystallized human plasma albumin was used as the antigen. ${ }^{8}$

\section{RESULTS}

The data are summarized in Tables I and II and Figure 1.

\section{Inulin clearance}

The inulin clearance rose at least slightly in most of the patients either during or, more often, after the ACTH treatment as reported previously by other workers $(7,8,12)$. When initially subnormal, this function often rose to normal; if initially normal, it tended to become supernormal.

\section{Creatinine clearance}

As was first shown by Miller and Winkler (26) and subsequently confirmed by others $(3,8,27)$, the specific endogenous creatinine clearance exceeded the inulin clearance before ACTH treatment; the highest value of the ratio, $\mathrm{C}_{\mathrm{CR}} / \mathrm{C}_{\mathrm{IN}}$, was 2.65. During and after ACTH therapy, usually in association with a rise in both clearances, the ratio decreased toward the normal value of 1.0 as described previously (8).

\section{T-1824 clearance}

In all patients, the dye clearance decreased markedly during and after treatment whether the inulin clearance increased or not. Expressed as the ratio, $C_{T-1824} / C_{I N}$, the effect was striking; in all but two cases the decrease was 10 -fold or more.

\section{Comparison of simultaneously measured clearances of $T-1824$ and albumin}

The data are summarized in Table II. Technical difficulties were encountered in the immunochemical determination of albumin. Furthermore, the very low urinary concentrations of albumin and dye in the post-ACTH periods undoubtedly re-

8 Generous quantities of this albumin were obtained from the Department of Physical Chemistry, Harvard University, through the courtesy of Dr. David Gitlin. 


\begin{tabular}{|c|c|c|c|c|c|c|c|c|c|c|c|}
\hline \multirow{2}{*}{$\begin{array}{l}\text { Patient } \\
\text { (hoopital } \\
\text { number) }\end{array}$} & \multirow[b]{2}{*}{ Sex } & \multirow[b]{2}{*}{ Age } & \multirow{2}{*}{$\begin{array}{c}\text { Duration } \\
\text { of } \\
\text { illness }\end{array}$} & \multirow[b]{2}{*}{ Height } & \multirow{2}{*}{$\begin{array}{c}\text { Ideal } \\
\text { weight }\end{array}$} & \multirow{2}{*}{$\begin{array}{c}\text { Ideal } \\
\text { surface } \\
\text { area }\end{array}$} & \multirow[b]{2}{*}{ Date } & \multirow{2}{*}{$\begin{array}{c}\text { Observed } \\
\text { weight* }\end{array}$} & \multicolumn{2}{|c|}{ ACTH therapy } & \multirow{2}{*}{$\begin{array}{c}\text { Time of } \\
\text { obimervation } \\
\text { in relation } \\
\text { to ACTH } \\
\text { administration } \\
\end{array}$} \\
\hline & & & & & & & & & Duration & Dose & \\
\hline$\underset{(580366)}{\stackrel{(1)}{P} .}$ & $\stackrel{(2)}{\mathbf{M}}$ & $\begin{array}{l}\text { years } \\
3\end{array}$ & $\begin{array}{c}\text { months } \\
(4) \\
7\end{array}$ & $\begin{array}{l}\text { (5). } \\
95.0\end{array}$ & $\begin{array}{r}K g \\
(6) \\
14.7\end{array}$ & $\begin{array}{c}M 2 \\
(7) \\
0.60\end{array}$ & $\begin{array}{l}\stackrel{(8)}{11-1-50} \\
11-7-50 \\
11-13-50\end{array}$ & $\begin{array}{c}K_{g} . \\
(9) \\
17.2 \\
17.6 \\
15.3\end{array}$ & $\begin{array}{c}\begin{array}{c}d a y s \\
(10)\end{array} \\
8\end{array}$ & $\begin{array}{c}\text { mg./24 hrs. } \\
\text { (11) } \\
50\end{array}$ & $\begin{array}{c}\text { (12) } \\
1 \text { day before } \\
\text { 7th day of ACTH } \\
5 \text { days after }\end{array}$ \\
\hline$\underset{(576554)}{\mathrm{J}} \cdot \underset{ }{H}$ & $\mathbf{M}$ & $4 \frac{1}{2}$ & 20 & 95.3 & 14.8 & 0.61 & $\begin{array}{l}11-10-50 \\
11-17-50 \\
11-27-50\end{array}$ & $\begin{array}{l}20.4 \\
21.1 \\
22.1\end{array}$ & 10 & 100 & $\begin{array}{l}1 \text { day before } \\
\text { 7th day of ACTH } \\
7 \text { days after }\end{array}$ \\
\hline$\underset{(586965)}{\text { E. B. }}$ & $\mathbf{F}$ & $4 \frac{1}{2}$ & 4 & 106.0 & 17.7 & 0.69 & $\begin{array}{l}12-6-50 \\
12-15-50 \\
12-19-50\end{array}$ & $\begin{array}{l}21.7 \\
21.5 \\
18.1\end{array}$ & 4 & 50 & $\begin{array}{l}10 \text { days before } \\
1 \text { day before } \\
\text { 4th day of ACTH }\end{array}$ \\
\hline$\underset{\text { (588663) }}{\text { M. B. }}$ & $\mathbf{F}$ & $1 \frac{3}{6}$ & 2 & 81.5 & 10.9 & 0.48 & $\begin{array}{l}1-5-51 \\
1-17-51\end{array}$ & $\begin{array}{l}12.5 \\
11.9\end{array}$ & 10 & 50 & $\begin{array}{l}3 \text { days before } \\
\text { 10th day of ACTH }\end{array}$ \\
\hline$\underset{\text { (581715) }}{\text { W. H. }}$ & $\mathbf{F}$ & $2 \frac{1}{2}$ & 11 & 77.0 & 9.8 & 0.44 & $\begin{array}{l}2-7-51 \\
2-13-51 \\
2-20-51 \\
2-26-51\end{array}$ & $\begin{array}{r}18.1 \\
10.7 \\
7.9 \\
8.2\end{array}$ & 10 & 50 & $\begin{array}{l}3 \text { days before } \\
\text { 10th day of ACTH } \\
7 \text { days after } \\
13 \text { days after }\end{array}$ \\
\hline$\underset{\text { (574414) }}{\text { P.S. }}$ & $\mathbf{M}$ & $2 \frac{1}{2}$ & 9 & 88.0 & 12.9 & 0.55 & $\begin{array}{l}2-8-51 \\
2-12-51 \\
2-19-51\end{array}$ & $\begin{array}{l}16.7 \\
16.9 \\
17.1\end{array}$ & 6 & 50 & $\begin{array}{c}6 \text { days before } \\
2 \text { days before } \\
\text { 6th day of ACTH }\end{array}$ \\
\hline$\underset{(590159)}{\text { H.G. }}$ & $\mathbf{F}$ & 2 & 6 & 87.0 & 12.5 & 0.53 & $\begin{array}{l}2-9-51 \\
2-14-51 \\
2-21-51 \\
2-27-51\end{array}$ & $\begin{array}{l}13.7 \\
14.2 \\
12.1 \\
12.4\end{array}$ & 10 & 50 & $\begin{array}{l}1 \text { day before } \\
\text { 6th day of ACTH } \\
3 \text { days after } \\
9 \text { days after }\end{array}$ \\
\hline B. B. L. & $\mathbf{F}$ & $3 \frac{3}{4}$ & 7 & 101.5 & 16.4 & 0.65 & $\begin{array}{l}3-16-51 \\
3-21-51 \\
4-5-51\end{array}$ & $\begin{array}{l}21.6 \\
22.8 \\
20.0\end{array}$ & 10 & 50 & $\begin{array}{l}3 \text { days before } \\
\text { 3rd day of ACTH } \\
8 \text { days after }\end{array}$ \\
\hline$\underset{(604205)}{\text { D. E. }}$ & $\mathbf{M}$ & $4 z$ & 9 & 101.0 & 16.3 & 0.65 & $\begin{array}{l}7-11-51 \\
7-20-51\end{array}$ & $\begin{array}{l}20.6 \\
14.2\end{array}$ & 5 & 50 & $\begin{array}{l}2 \text { days before } \\
3 \text { days after }\end{array}$ \\
\hline$\underset{(597510)}{\text { C.S. }}$ & $\mathbf{M}$ & $3 t$ & 15 & 100.0 & 16.2 & 0.64 & $\begin{array}{l}6-3-52 \\
6-18-52\end{array}$ & $\begin{array}{l}28.3 \\
24.0\end{array}$ & 10 & $75-100 \$ 8$ & $\begin{array}{l}2 \text { days before } \\
4 \text { days after }\end{array}$ \\
\hline $\begin{array}{l}\text { F. deK. } \\
\text { (576121) }\end{array}$ & $\mathbf{M}$ & $7 \frac{1}{2}$ & 38 & 114.0 & 20.7 & 0.79 & $\begin{array}{l}3-20-51 \\
3-30-51 \\
4-9-51\end{array}$ & $\begin{array}{l}21.1 \\
22.3 \\
23.0\end{array}$ & 10 & 50 & $\begin{array}{c}4 \text { days before } \\
\text { 7th day of ACTH } \\
7 \text { days after }\end{array}$ \\
\hline
\end{tabular}

* In some cases, further weight loss ensued after the time of the last observation.

* Upper respiratory infection occurred between first and second observations.

$8875 \mathrm{mg}$. per $24 \mathrm{hrs}$. for four days, then $100 \mathrm{mg}$. per $24 \mathrm{hrs}$. for next six days.

sulted in large percentage errors in measuring the concentrations of both substances. Therefore, although the clearance ratio deviated from 1.0 to a considerable extent in some instances, the order of magnitude of $C_{A L B}$ was estimated sufficiently well by $C_{1-1824}$ for the purposes of the present investigation.

\section{Total protein excretion}

The decrease in total protein excretion during and after ACTH therapy was large in all cases. being roughly parallel to the decrease in $C_{T-1824} /$ $\mathrm{C}_{\mathrm{IN}}$ (Tables I and II). The ratio, total protein excretion/ $\mathrm{C}_{\mathrm{IN}}$, provides a minimum estimate of the concentration of protein in the glomerular fluid (assuming no protein is secreted into the urine by the tubules). This ratio likewise decreased markedly.

\section{Plasma and whole blood volume}

Observations that the plasma volume usually increases after ACTH treatment (8) were not sus- 
TABLE I-Continued

Summary of data

\begin{tabular}{|c|c|c|c|c|c|c|c|c|c|c|}
\hline \multirow{2}{*}{$\begin{array}{c}\begin{array}{c}\text { Plasma } \\
\text { volume }\end{array} \\
\begin{array}{c}m l . \\
(13)\end{array}\end{array}$} & \multirow{2}{*}{$\begin{array}{c}\begin{array}{c}\text { Blood } \\
\text { volume }\end{array} \\
\begin{array}{c}m l \\
(14)\end{array}\end{array}$} & \multicolumn{2}{|c|}{ Cint } & \multirow{2}{*}{$\frac{\mathrm{C}_{\mathrm{CR}} / \mathrm{C}_{\mathrm{Int}}}{\text { (17) }}$} & \multirow{2}{*}{$\frac{\text { CPABt }}{\text { ml./mine. }}$} & \multirow{2}{*}{$\frac{C_{T-1 n e n t}}{m_{(19)} / \text { min. }}$} & $\frac{C_{T-1004}}{C_{C R}}$ & $\frac{\substack{\text { Estimated } \\
\mathrm{C}_{\mathrm{T}-\min }}}{\mathrm{C}_{\mathrm{IM}}}$ & $\begin{array}{c}\text { Total } \\
\text { protein } \\
\text { excretion \| }\end{array}$ & $\frac{\begin{array}{c}\text { Estimated } \\
\text { total } \\
\text { protein } \\
\text { excretion }\end{array}}{\text { CIII }}$ \\
\hline & & $\underset{\text { (15) }}{\operatorname{ml} / \text { min. }}$ & $\begin{array}{c}\text { Per cent } \\
\text { of normal } \\
\text { (16) }\end{array}$ & & & & $\begin{array}{c}m l . / 100 \mathrm{ml} . \\
(20)\end{array}$ & $\begin{array}{c}m l . / 100 \mathrm{ml} . \\
(21)\end{array}$ & mg./min. & $\begin{array}{c}m s . / 100 \\
(23)\end{array}$ \\
\hline $\begin{array}{l}735 \\
730 \\
725\end{array}$ & $\begin{array}{l}1,265 \\
1,110 \\
1,115\end{array}$ & $\begin{array}{l}19.7 \\
25.2 \\
53.0\end{array}$ & $\begin{array}{r}47 \\
60 \\
126\end{array}$ & $\begin{array}{l}2.65 \\
1.77 \\
1.30\end{array}$ & $\begin{array}{l}145 \\
113 \\
200\end{array}$ & $\begin{array}{l}0.205 \\
0.054 \\
0.002\end{array}$ & $\begin{array}{l}0.47 \\
0.13 \\
0.003\end{array}$ & $\begin{array}{l}1.3 \\
0.22 \\
0.004\end{array}$ & & \\
\hline $\begin{array}{l}765 \\
680 \\
690\end{array}$ & $\begin{array}{l}1,020 \\
1,165 \\
1,080\end{array}$ & $\begin{array}{r}6.3 \\
7.1 \\
10.9\end{array}$ & $\begin{array}{l}15 \\
17 \\
26\end{array}$ & $\begin{array}{l}1.60 \\
1.53 \\
1.42\end{array}$ & $\begin{array}{l}39.1 \\
29.3\end{array}$ & $\begin{array}{l}0.176 \\
0.080\end{array}$ & $\begin{array}{l}1.7 \\
0.47\end{array}$ & $\begin{array}{l}2.7 \\
0.67\end{array}$ & & \\
\hline \multirow{2}{*}{$\begin{array}{l}645 \\
720 \\
795\end{array}$} & 1,045 & 36.0 & 75 & 1.99 & 312 & \multirow{2}{*}{$\begin{array}{l}0.185 \\
0.054 \\
0.005\end{array}$} & \multirow{2}{*}{$\begin{array}{l}0.27 \\
0.11 \\
0.007\end{array}$} & 0.53 & & \\
\hline & 1,185 & 57.9 & 121 & 1.28 & 271 & & & 0.009 & & \\
\hline $\begin{array}{l}420 \\
470\end{array}$ & $\begin{array}{l}725 \\
725\end{array}$ & & & & & $\begin{array}{l}0.054 \\
0.002\end{array}$ & $\begin{array}{l}0.12 \\
0.004\end{array}$ & & & \\
\hline $\begin{array}{l}555 \\
420 \\
440 \\
445\end{array}$ & $\begin{array}{l}725 \\
665 \\
670 \\
640\end{array}$ & $\begin{array}{r}8.8 \\
8.0 \\
11.7 \\
22.4\end{array}$ & $\begin{array}{l}29 \\
26 \\
38 \\
73\end{array}$ & $\begin{array}{l}1.59 \\
1.30 \\
2.23 \\
1.07\end{array}$ & $\begin{array}{l}37.2 \\
37.9 \\
52.7 \\
82.4\end{array}$ & $\begin{array}{l}0.183 \\
0.035 \\
0.024 \\
0.085\end{array}$ & $\begin{array}{l}1.4 \\
0.33 \\
0.078 \\
0.29\end{array}$ & $\begin{array}{l}2.2 \\
0.43 \\
0.17 \\
0.31\end{array}$ & $\begin{array}{l}4.5 \\
0.6 \\
0.4 \\
2.4\end{array}$ & $\begin{array}{r}54.0 \\
6.7 \\
2.9 \\
10.4\end{array}$ \\
\hline $\begin{array}{l}660 \\
750 \\
845\end{array}$ & $\begin{array}{l}1,040 \\
1,210 \\
1,325\end{array}$ & $\begin{array}{l}51.0 \\
47.4 \\
56.2\end{array}$ & $\begin{array}{l}134 \\
125 \\
148\end{array}$ & $\begin{array}{l}1.48 \\
1.27 \\
1.45\end{array}$ & $\begin{array}{l}136 \\
173 \\
156\end{array}$ & $\begin{array}{l}0.153 \\
0.049 \\
0.010\end{array}$ & $\begin{array}{l}0.20 \\
0.10 \\
0.012\end{array}$ & $\begin{array}{l}0.29 \\
0.13 \\
0.017\end{array}$ & $\begin{array}{l}2.4 \\
1.9 \\
0.2\end{array}$ & $\begin{array}{l}4.8 \\
4.1 \\
0.4\end{array}$ \\
\hline $\begin{array}{l}490 \\
480 \\
500\end{array}$ & $\begin{array}{l}855 \\
890 \\
825\end{array}$ & $\begin{array}{l}35.0 \\
43.8 \\
29.7 \\
38.6\end{array}$ & $\begin{array}{r}95 \\
118 \\
80 \\
104\end{array}$ & $\begin{array}{l}1.04 \\
1.16 \\
1.62 \\
0.88\end{array}$ & $\begin{array}{l}143 \\
186 \\
149 \\
137\end{array}$ & $\begin{array}{l}0.071 \\
0.026 \\
0.095 \\
0.004\end{array}$ & $\begin{array}{l}0.25 \\
0.066 \\
0.21 \\
0.015\end{array}$ & $\begin{array}{l}0.26 \\
0.077 \\
0.34 \\
0.013\end{array}$ & $\begin{array}{l}2.3 \\
1.0 \\
1.3 \\
0.0\end{array}$ & $\begin{array}{l}6.6 \\
2.0 \\
4.7 \\
0.0\end{array}$ \\
\hline \multirow{2}{*}{$\begin{array}{l}720 \\
635\end{array}$} & \multirow{2}{*}{$\begin{array}{l}1,100 \\
1,050\end{array}$} & $18.1 \mathrm{ft}$ & 40 & 2.81 & & \multirow{2}{*}{$\begin{array}{l}0.58 \\
0.47 \\
0.19\end{array}$} & \multirow{2}{*}{$\begin{array}{l}1.05 \\
1.27 \\
0.27\end{array}$} & 2.95 & \multirow{2}{*}{$\begin{array}{l}3.0 \\
1.8 \\
1.8\end{array}$} & 13.8 \\
\hline & & $41.9 \ddagger \ddagger$ & 93 & 1.52 & & & & 0.43 & & 4.4 \\
\hline $\begin{array}{l}715 \\
720\end{array}$ & $\begin{array}{l}1,070 \\
1,070\end{array}$ & $\begin{array}{l}26.9 \\
55.2\end{array}$ & $\begin{array}{r}60 \\
122\end{array}$ & $\begin{array}{l}1.68 \\
1.20\end{array}$ & $\begin{array}{l}156 \\
228\end{array}$ & $\begin{array}{l}0.124 \\
0.002\end{array}$ & $\begin{array}{l}0.28 \\
0.003\end{array}$ & $\begin{array}{l}0.47 \\
0.003\end{array}$ & 1.8 & 6.7 \\
\hline 1,065 & 1,390 & $\begin{array}{l}21.4 \\
25.3\end{array}$ & $\begin{array}{l}48 \\
56\end{array}$ & $\begin{array}{l}1.51 \\
1.35\end{array}$ & $\begin{array}{l}194 \\
145\end{array}$ & $\begin{array}{l}0.82 \\
0.084\end{array}$ & $\begin{array}{l}2.52 \\
0.22\end{array}$ & $\begin{array}{l}3.80 \\
0.30\end{array}$ & $\begin{array}{l}7.2 \\
1.8\end{array}$ & $\begin{array}{r}40.9 \\
6.5\end{array}$ \\
\hline $\begin{array}{r}1,160 \\
1,085 \\
985\end{array}$ & $\begin{array}{l}2,000 \\
1,870 \\
1,690\end{array}$ & $\begin{array}{l}21.9 \\
25.5 \\
23.2\end{array}$ & $\begin{array}{l}40 \\
46 \\
42\end{array}$ & $\begin{array}{l}1.47 \\
1.36 \\
1.67\end{array}$ & $\begin{array}{l}64.6 \\
76.5 \\
76.2\end{array}$ & $\begin{array}{l}0.016 \\
0.005 \\
0.001\end{array}$ & $\begin{array}{l}0.047 \\
0.015 \\
0.004\end{array}$ & $\begin{array}{l}0.069 \\
0.021 \\
0.006\end{array}$ & $\begin{array}{l}1.3 \\
0.2 \\
0.2\end{array}$ & $\begin{array}{l}5.6 \\
0.7 \\
1.0\end{array}$ \\
\hline
\end{tabular}

Data from periods $U_{2-4}$.

$\mp$ Data from period $U_{2}$.

Calculated by multiplying the value for $\mathrm{C}_{\mathrm{T}-182} / \mathrm{C}_{\mathrm{CR}}$, shown in column 20 , by the value for mean $\mathrm{C}_{\mathrm{CR}} / \mathrm{C}_{\mathrm{IN}}$, measured in periods $U_{2 \rightarrow}$ and shown in column 17.

$\|$ Data from control period preceding period $U_{1}$.

Calculated by dividing the value in column 22 by the estimated $\mathrm{C}_{\mathrm{IN}}$. The latter was estimated by dividing the observed $C_{C R}$ by the value for mean $C_{C R} / C_{I N}$ shown in column 17.

tf Datum from study of 3-13-51.

$\$$ Datum from study of $4-6-51$.

tained by the present data (Table I). More often than not, the plasma volume did not increase significantly.

\section{DISCUSSION}

Hypotheses concerning the mechanism of proteinuria in children with the nephrotic syndrome were recently discussed by Chinard, Lauson, Eder, Greif, and Hiller, (1) and reviewed by Smith (28) and by Barnett, Forman, and Lauson (2). It has been shown (1) that following administration of concentrated human plasma albumin the calculated minimum concentrations of protein in the glomerular fluid commonly exceeded $100 \mathrm{mg}$. per 


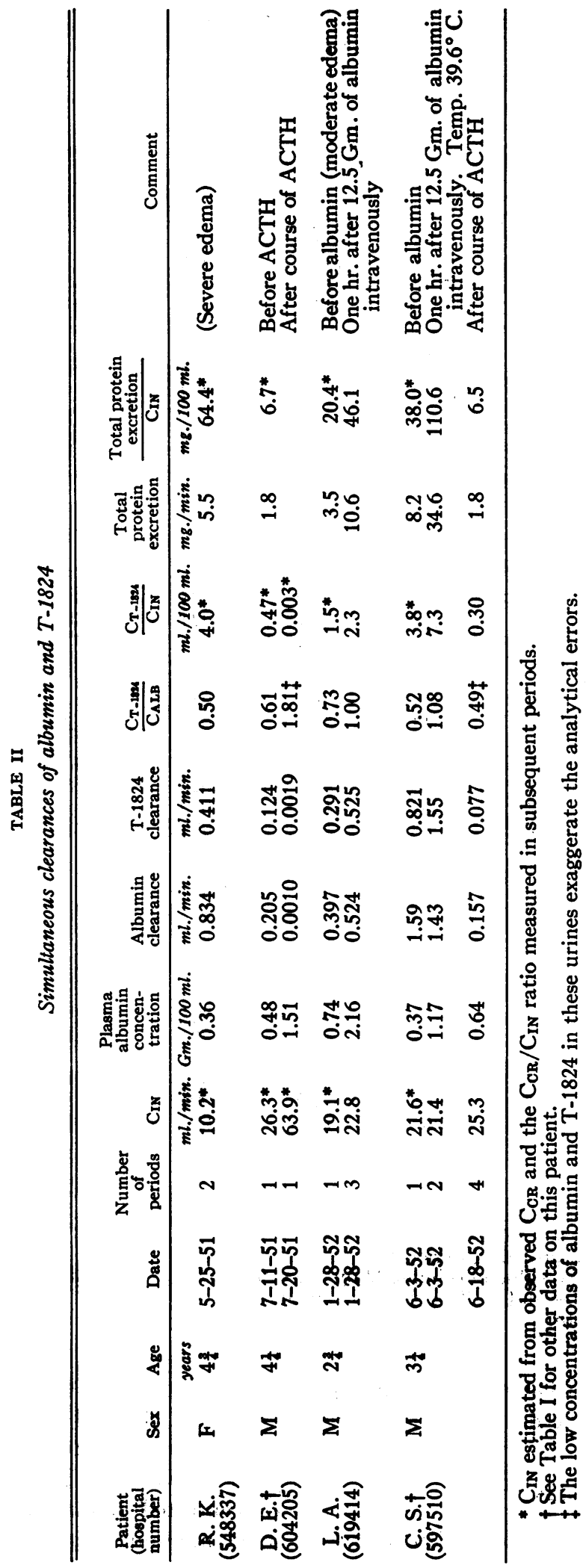




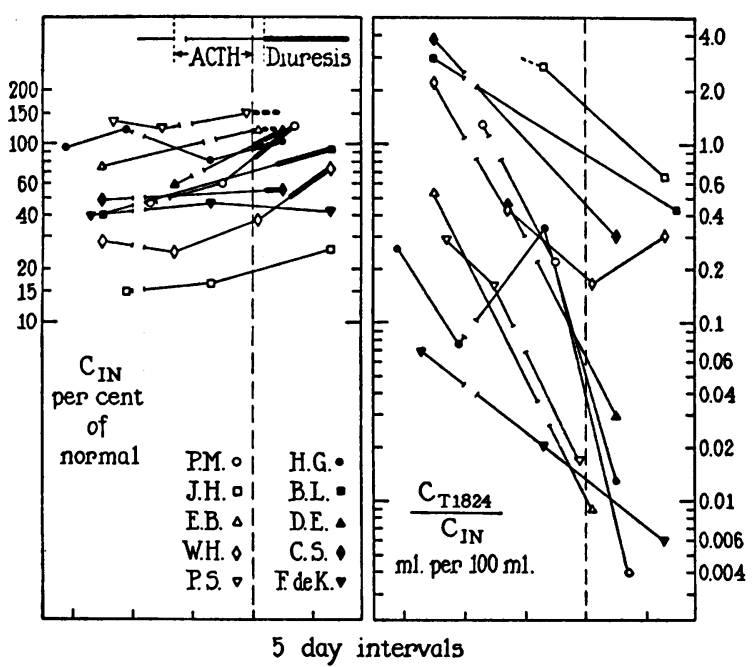

Fig. 1. Changes in Inulin Clearance (C $\mathrm{C}_{\mathrm{in}}$ ) (Left) and in the Ratio of T-1824 and Inulin Clearances

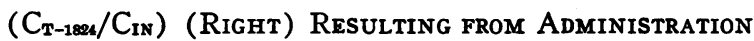
of Corticotropin (ACTH) in Children with the NePHROTIC SYNDROME

See Text for method of estimating $C_{T-1824} / C_{I N}$. The break in the lines connecting the symbols indicates the first day of ACTH treatment. The interrupted vertical line in each graph indicates the end of the last day of ACTH administration. The thickened section of the lines connecting the symbols (left) indicates the presence and duration of diuresis.

$100 \mathrm{ml}$; values as high as $193 \mathrm{mg}$. per $100 \mathrm{ml}$. were observed. These data, therefore, were not compatible with the view that proteinuria in children with the nephrotic syndrome results from a failure of the renal tubules to absorb the 20 or 30 mg. of protein commonly assumed to pass through normal glomerular walls with each $100 \mathrm{ml}$. of filtrate. For this and other reasons, it was concluded that proteinuria in the nephrotic syndrome was due to an increase in the glomerular permeability to proteins, especially to albumin (1).

In the control studies on three patients of the present report (W. H. and C. S., Table I, and R. $\mathrm{K}$., Table II) minimum concentrations of protein in glomerular fluid were 54, 41, and $64 \mathrm{mg}$. per $100 \mathrm{ml}$., respectively. After infusion of concentrated albumin, values of 46 and $111 \mathrm{mg}$. per 100 $\mathrm{ml}$., respectively, were obtained in patients L. A. and C. S. (Table II). All of these concentrations exceed the assumed normal values of 20 to $30 \mathrm{mg}$. per $100 \mathrm{ml}$. These results, therefore, are in agree- ment with those of Chinard, Lauson, Eder, Greif, and Hiller (1).

To the extent that the ratio, $\mathrm{C}_{\mathrm{T}-\mathbf{1 8 2 4}} / \mathrm{C}_{\mathrm{IN}}$, estimates the ratio, $C_{A L B} / C_{I N}$, and to the extent that the latter provides a rough indication of the minimum permeability of the glomerular walls to albumin, relative to the permeability to water, the data of the present investigation clearly indicate that treatment with ACTH (and presumably also with Cortisone) results in a marked degree of reversal of the functional pathology in the glomeruli. The usual increase in GFR may be considered another aspect of this same restorative process. As discussed in detail elsewhere (2), it is our present opinion that these effects on the glomeruli are primary and that most of the other beneficial effects of the treatment are secondary.

\section{SUMMARY}

Simultaneous renal clearances of the blue dye, $\mathrm{T}-1824\left(\mathrm{C}_{\mathrm{T}-1824}\right)$, and of albumin $\left(\mathrm{C}_{\mathrm{ALB}}\right)$ have been shown to be nearly the same in patients with the nephrotic syndrome (4). Furthermore, the ratio of the clearances of albumin and inulin $\left(C_{A L B} / C_{I N}\right)$ provides a rough indication of the minimum glomerular permeability to albumin, relative to the permeability to water.

In 10 edematous children with the nephrotic syndrome the ratio, $\mathrm{C}_{\mathrm{T}-1824} / \mathrm{C}_{\mathrm{IN}}$, ranged from 0.26 to $3.8 \mathrm{ml}$. per $100 \mathrm{ml}$. before treatment with corticotropin (ACTH). Glomerular filtration rate (GFR), as estimated by $\mathrm{C}_{\mathrm{IN}}$, ranged from 15 to 134 per cent of average normal. From 50 to 100 $\mathrm{mg}$. of ACTH per day were given intramuscularly in divided dosage every six hours for from four to ten days. By the end of, or a few days after, the course of injections, $C_{T-1824} / C_{\text {IN }}$ had decreased strikingly in all patients : more than 10-fold in all but two. $\mathrm{C}_{\mathrm{IN}}$ increased at least slightly in most cases and more than doubled in four. Similar results were observed in one non-edematous boy with chronic glomerular nephritis who excreted only 1 to 2 grams of protein per day. In the control study, $C_{\mathrm{T}-1824} / \mathrm{C}_{\mathrm{IN}}$ was only $0.07 \mathrm{ml}$. per 100 $\mathrm{ml}$; after ACTH it had decreased to $0.006 \mathrm{ml}$. per $100 \mathrm{ml}$.

The data of this investigation are interpreted as indicating that one of the favorable effects of ACTH treatment is a reversal toward normal of 
the increased glomerular permeability to albumin (and other plasma proteins). The same restorative process is presumably responsible for some of the observed increase in GFR. These effects of therapy on the glomeruli are considered to be primary to most of the other beneficial results.

\section{ACKNOWLEDGMENTS}

We are indebted to Flora Hurwitz, R. N., for nursing and technical assistance, and to Emily Matejka and Gladys Folkart for technical assistance.

\section{REFERENCES}

1. Chinard, F. P., Lauson, H. D., Eder, H. A., Greif, R. L., and Hiller, A., A study of the mechanism of proteinuria in patients with the nephrotic syndrome. J. Clin. Invest., 1954, 33, 621.

2. Barnett, H. L., Forman, C. W., and Lauson, H. D., The Nephrotic Syndrome in Children in Advances in Pediatrics, New York, Year Book Publishers, Inc., 1952, v.

3. Mattar, G., Barnett, H. L., McNamara, H., and Lauson, $\mathrm{H}$. D., Measurement of glomerular filtration rate in children with kidney disease. J. Clin. Invest., 1952, 31, 938.

4. Chinard, F. P., Lauson, H. D., and Eder, H. A., Relationship of the renal clearances of T-1824 and of albumin in some patients with proteinuria. J. Clin. Invest., 1952, 31, 895.

5. Kunkel, H. G., and Ward, S. M., The immunological determination of human albumin in biological fluids. J. Biol. Chem., 1950, $182,597$.

6. Luetscher, J. A., Jr., and Deming, Q. B., Treatment of nephrosis with cortisone. J. Clin. Invest., 1950, 29, 1576.

7. Luetscher, J. A., Jr., Deming, Q. B., and Johnson, B. B., Treatment of nephrosis with pituitary adrenocorticotrophin. J. Clin. Invest., 1951, 30, 1530.

o. Barnett, H. L., Forman, C. W., McNamara, H., McCrory, W. W., Rapoport, M., Michie, A. J., and Barbero, G., The effect of adrenocorticotrophic hormone on children with the nephrotic syndrome. II. Physiologic observations on discrete kidney functions and plasma volume. J. Clin. Invest., 1951, 30, 227.

9. Rapoport, M., McCrory, W. W., Barbero, G., Barnett, H. L., Forman, C. W., and McNamara, H., Effect of corticotropin (ACTH) on children with the nephrotic syndrome. J. A. M. A., 1951, 147, 1101.

10. Riley, C. M., Nephrotic syndrome. Effect of adrenocorticotrophic hormone. Pediatrics, 1951, 7, 457.

11. Bjørneboe, M., Brun, C., Gormsen, H., Iversen, P., and Raaschou, $F$., The nephrotic syndrome. II. The effect of corticotropin (ACTH). Acta med. Scandinav., 1952, 142 (Suppl. 266), 249.
12. Metcoff, J., Rance, C. P., Kelsey, W. M., Nakasone, N., and Janeway, C. A., Adrenocorticotrophic hormone (ACTH) therapy of the nephrotic syndrome in children. Pediatrics, 1952, 10, 543.

13. Arneil, G. C., and Wilson, H. E. C., Cortisone treatment of nephrosis. Arch. Dis. Childhood, 1952, 27, 322.

14. McCall, M. F., Ross, A., Wolman, B., Burns, A. D., Harpur, E. M., and Goldbloom, A., The nephrotic syndrome in children treated with ACTH and cortisone. Arch. Dis. Childhood, 1952, 27, 309.

15. Keith, N. M., Power, M. H., Daugherty, G. W., and Keith, H. M., Some effects of cortisone on metabolic disturbance associated with renal edema. Arch. Int. Med., 1952, 89, 689.

16. Kramer, B., Goldman, H., and Cason, L., The treatment of the nonedematous nephrotic child with ACTH. J. Pediat., 1952, 41, 792.

17. Kramer, B., Casden, D. D., Goldman, H., and Silverman, S. H., Effect of the adrenocorticotropic hormone (ACTH) on nephrosis in childhood. Postgrad. Med., 1952, 11, 439.

18. Lauson, H. D., Forman, C. W., McNamara, H., Mattar, G., and Barnett, H. L., Effect of corticotropin (ACTH) on glomerular permeability to albumin and on blood antidiuretic hormone concentration in children with the nephrotic syndrome. Am. J. Dis. Child., 1952, 83, 87.

19. Barnett, H. L., and Fellers, F. X., A simple quantitative method for intravenous injection of small volumes of fluid. Science, 1947, 106, 401.

20. Chinard, F. P., and Eder, H. A., The determination of the concentration of the dye T-1824 in normal and lipemic plasmas. J. Exper. Med., 1948, 87, 473.

21. Goldring, W., and Chasis, H., Hypertension and $\mathrm{Hy}-$ pertensive Disease. New York, The Commonwealth Fund, 1944.

22. Schreiner, G. E., Determination of inulin by means of resorcinol. Proc. Soc. Exper. Biol. \& Med., 1950, 74, 117.

23. Hare, R. S., Endogenous creatinine in serum and urine. Proc. Soc. Exper. Biol. \& Med., 1950, 74, 148.

24. Wu, H., Separate analyses of the corpuscles and the plasma. J. Biol. Chem., 1922, 51, 21.

25. Hiller, A., Greif, R. L., and Beckman, W. W., Determination of protein in urine by the biuret method. J. Biol. Chem., 1948, 176, 1421.

26. Miller, B. F., and Winkler, A. W., The renal excretion of endogenous creatinine in man. Comparison with exogenous creatinine and inulin. J. Clin. Invest., 1938, 17, 31.

27. Hare, K., Goldstein, H., Barnett, H. L., McNamara, H., and Hare, R. S., Renal excretion of creatinine in man. Federation Proc., 1949, 8, 67.

28. Smith, H. W., The Kidney. Structure and Function in Health and Disease. New York, Oxford University Press, 1951. 